\title{
IMPROVING THE COMPETENCE OF TEACHERS IN MAKING CLASSROOM ACTION RESEARCH THROUGH MGMP IN SMP NEGERI 23 PONTIANAK
}

\author{
By:
}

Saryana $^{1}$

\begin{abstract}
The duties and obligations of teachers in addition to educate as well as researchers, the research attempted amending the learning. One of the forms was to improve the competence in conducting research was by means of Musyawarah Guru Mata Pelajaran (MGMP). This activity aimed to improve the competence of teacher in creating classroom action research, expectedly being able to improve the quality of learning process for teachers in the classroom, and improve student learning outcomes eventually. This research was conducted at SMP Negeri 23 Pontianak on September until December 2012. The subject of research was the teachers of SMP Negeri 23 about 27 people. This research was carried out using school action research design, designed through 3 cycles, each cycle through these steps: planning, implementation, observation and reflection. The competence of teacher in using classroom action research in cycle I is $38,82 \%$ in low categories. The competence of teachers in using classroom action research in cycle II is $78,33 \%$ in very high category. It was concluded that the competence of SMP Negeri 23 Pontianak in classroom action research from cycle I to cycle II increase of 39,51\%. From 27 teachers in SMP Negeri 23 Pontianak, who finished doing classroom action research to the number of 14 people. The number of teachers who did not conduct classroom action research to the number of 4 people. There were 2 teachers who could only follow 1 section. As many as 7 teachers could follow more than 2 times but they did not finish to make reports. At the beginning state before following the MGMP in SMP Negeri 23 Pontianak there were 2 teachers had ever done research and after following the MGMP there were 14 teachers who finished doing the classroom action research. There was raising in number of teachers who had the competency to do classroom action research as many as 12 people. It is concluded that once made MGMP at SMP Negeri 23 Pontianak is increasing the competence of teachers in making classroom research action as many as 12 people.
\end{abstract}

Kata kunci: kompetensi membuat PTK

\footnotetext{
${ }^{1}$ Saryana : Kepala Sekolah SMPN 23 Pontianak
} 
Undang-undang RI Nomor 14 Tahun 2005 tentang Guru dan Dosen mengamanatkan guru antara lain untuk memiliki kompetensi sebagai agen pembelajaran yaitu kompetensi pedagogik, kepribadian, kompetensi sosial, dan kompetensi profesional. Agar guru dapat memiliki kompetensi sebagai agen pembelajaran sebagaimana yang diamanatkan pada undang-undang tersebut di atas, maka guru harus senantiasa meningkatkan kompetensinya secara terus menerus melalui berbagai upaya antara lain pelatihan, kegiatan karya tulis ilmiah, pertemuan di kelompok kerja dan musyawarah kerja yang yang diantaranya Musyawarah Guru Mata Pelajaran (MGMP).

Menurut Suharsimi Arikunto (2009: 1) diantara butir kompetensi profesional guru, yaitu kemampuan melakukan penelitian dalam rangka meningkatkan kualitas profesional guru, khususnya kualitas pembelajaran. Penelitian yang disarankan untuk guru adalah penelitian tindakan. Penelitian tindakan dimaksudkan untuk meningkatkan hasil belajar siswa. Penelitian tindakan kelas bukan sekedar mengajar seperti biasanya, tetapi mengandung pengertian bahwa tindakan yang dilakukan didasarkan pada upaya meningkatkan hasil, yaitu lebih baik dari sebelumnya. Salah satu upaya SMP Negeri 23 Pontianak yang dilakukan untuk pencapaian kompetensi guru membuat penelitian kelas adalah dengan mengadakan Musyawarah Guru Mata Pelajaran (MGMP).

Salah satu indikator kompetensi profesional adalah kompetensi pengembangan profesi, antara lain melakukan penelitian tindakan kelas. Namun kenyataannya di lapangan menunjukkan bahwa masih banyak guru yang perlu penguatan dan peningkatan kemampuannya dalam bidang penelitian. Sebagiaan guru masih ada yang belum memahami bagaimana membuat proposal, melaksanakan, dan melaporkan hasil penelitian tindakan kelas dengan baik. Sebagian guru ada yang sudah memahami tetapi belum melakukannya. Untuk mengatasi hal tersebut SMP Negeri 23 Pontianak melaksanakan MGMP yang di dalamnya terdapat bimbingan teknik penelitian tindakan kelas. Bimbingan ini dimaksudkan dapat memberikan pemahaman dan motivasi guru untuk menyelesaikan permasalahannya di kelas melalui metode ilmiah yang antara lain berupa penelitian tindakan kelas. Apabila penyelesaian masalah di kelas dibiasakan melalui penelitian tindakan kelas, maka kompetensi guru akan meningkat dan berimplikasi pada peningkatan kreativitas, inovasi, pemecahan masalah, berpikir kritis, dan dapat menambah angka kredit guru dalaam pengusulan kenaikan pangkat. Tugas dan kewajiban guru selain mendidik juga sebagai peneliti, penelitian yang dikembangkan diupayakan untuk memperbaiki pembelajaran. Salah satu wadah untuk meningkatkan kompetensi membuat penelitian adalah melalui kegiatan Musyawarah Guru Mata Pelajaran (MGMP) di SMP Negeri 23 Pontianak. 
Kegiatan ini untuk meningkatkan mutu pembelajaraan bagi guru dan meningkatkan mutu pengelolaan sekolah bagi kepala sekolah. Peneliti sebagai kepala SMP Negeri 23 Pontianak melakukan Penelitian Tindakan Sekolah (PTS) dan guru sebagai peserta MGMP melakukan Penelitian Tindakan Kelas (PTK). Penelitian Tindakan Sekolah yang dilakukan peneliti merupakan penelitian yang berawal dari permasalahan di SMP Negeri 23 Pontianak yang akan diatasi melalui tindakan spesifik dari gagasan peneliti untuk mengatasi permasalahan yang dihadapi guru, terutama masalah guru dalam melakukan penelitian tindakaan kelas. Tindakan spesifik yang akan dilakukan adalah dengan mengadakan MGMP dan dalam kegiatan tersebut peneliti sebagai kepala sekolah melakukan bimbingan kepada guru untuk melaksanakan penelitian tindakan kelas.

Jumlah guru SMP Negeri 23 Pontianak tahun 2012 adalah 27 orang, dan yang mengisi angket berjumlah 21 orang. Berdasarkan angket yang diisi, tentang pendekatan kontekstual, mendapatkan data bahwa: (1) sudah menerapkan pendekatan kontekstual sebanyak 6 orang, kadang-kadang 5 orang, dan sebanyak 10 orang merasa belum melaksanakan secara baik, karena belum begitu paham. Sedangkan tentang penelitian tindakan kelas, hasil angket menunjukkan bahwa guru yang pernah melakukan penelitian tindakan kelas sebanyak 2 orang, dan 19 orang mengatakan belum pernah. Bagi mereka yang belum pernah membuat penelitian tindakan kelas beralasan bahwa: (1) belum terbiasa melakukan; (2) mengalami kesulitan dimana harus memulai; (3) kendala materi dan waktu; (4) belum mencoba melakukannya; (5) kesulitan menentukan rancangan penelitian; (5) belum paham tentang penelitian tindakan kelas.

Dari kondisi nyata tersebut peneliti mempunyai keinginan untuk mengadakan sebuah penelitian yang berjudul Peningkatan Kompetensi Guru dalam Membuat Penelitian Tindakan Kelas Melalui MGMP di SMP Negeri 23 Pontianak. Dalam penelitian ini peneliti sekaligus sebagai kepala sekolah berusaha untuk membantu guru dalam pembuatan penelitian tindakan kelas dengan mengadakan MGMP di SMP Negeri 23 Pontianak. Kegiatan ini bertujuan untuk meningkatkan kompetensi guru dalam membuat penelitian tindakan kelas, dengan harapan dapat meningkatkan mutu proses pembelajaran guru di kelas, dan pada akhirnya dapat meningkatkan hasil belajar siswa. Disamping itu guru melakukan penelitian tindakan kelas bertujuan untuk memperbaiki berbagai persoalan nyata dan praktis dalam peningkatan mutu pembelajaran di kelas, yang dialami langsung dalam interaksi antara guru dengan siswa.Penelitian ini akan memberi manfaat pada perbaikan kualitas guru di SMP Negeri 23 Pontianak secara nyata, seperti yang diharapkan bahwa 
dengan mengikuti MGMP guru SMP Negeri 23 Pontianak dapat membuat penelitian kelas.

Masalah dalam penelitian ini adalah rendahnya kompetensi guru dalam membuat penelitian tindakan kelas. Rumusan masalahnya adalah :"Apakah melalui MGMP di SMP Negeri 23 dapat meningkatkan kompetensi guru dalam membuat penelitian tindakan kelas ?" Penelitian tindakan sekolah ini bertujuan untuk meningkatkan kompetensi guru SMP Negeri 23 Pontianak dalam melakukan penelitian tindakan kelas melalui MGMP disekolah.

Menurut Mc. Load (dalam Suyanto dan Asep Djihad, 2012) mendefinisikan kompetensi sebagai perilaku yang rasional untuk mencapai tujuan yang dipersyaratkan sesuai dengan kondisi yang diharapkan. Kompetensi guru sendiri merupakan kemampuan seorang guru dalam melaksanakan kewajiban secara bertanggung jawab. Berdasarkan pada pengertian kompetensi diatas, kompetensi guru dapat diartikan sebagai gambaran tentang apa yang harus dilakukan seseorang guru dalam melaksanakan pekerjaannya, baik berupa kegiatan, perilaku maupu hasil yang dapat ditunjukkannya.

Musyawarah Guru Mata Pelajaran (MGMP) adalah forum atau wadah kegiatan profesional guru mata pelajaran yang berada pada satu wilayah/kabupaten/kota/ kecamatan/sanggar/gugus sekolah (Depdiknas, 2008: 6). MGMP di SMP Negeri 23 Pontianak merupakan kegiatan yang diselenggarakan sekolah di luar jam mengajar. Pesertanya adalah guru-guru yang berasal dari dalam SMP Negeri 23 Pontianak. Karena proses pembelajaran di SMP Negeri 23 Pontianak berlangsung pada siang hari, maka kegiatan ini dilaksanakan di hari Jumat pagi dari pukul 07.30 sampai pukul 10.30. Dalam kegiatan MGMP di SMP Negeri 23 Pontianak, kepala sekolah sebagai peneliti tindakan sekolah, memimpin, membimbing, dan memfasilitasi guru SMP Negeri 23 Pontianak untuk dapat melakukan penelitian tindakan kelas. Dalam kegiatan awal kepala sekolah menyampaikan tentang cara-cara dan teori dasar tentang pelaksanaan penelitian tindakan kelas.

Di setiap pertemuan dalam MGMP di SMP Negeri 23 Pontianak, kepala sekolah memberikan contoh cara membuat tiap Bab dalam laporan penelitian tindakan kelas. Dilanjutkan dengan menugaskan setiap peserta MGMP membuat sendiri tiap Bab dalam penelitian tindakan kelas yang dilakukan. Pada pertemuan-pertemuan berikutnya kepala sekolah, menanyakan hambatan-hambatan dan membantu memberikan solusinya. Diawal pertemuan berikutnya peserta MGMP diminta untuk mensimulasikan hasil pengamatan dan praktek pelaksanaan penelitian tindakan kelas. Dalam pertemuan tersebut peserta lain diminta untuk menanggapinya. Hal ini dilakukan sampai akhir 
siklus dan akhir penelitian. Dalam membuat laporan akhir, kepala sekolah memberi kebebasan waktu untuk konsultasi dan pemberian bimbingan.

\section{Metode}

Penelitian ini merupakan penelitian kualitatif dengan data yang diperoleh adalah data kualitatif dari hasil wawancara maupun observasi. Untuk menganalisis data tersebut dilakukan analisis deskriptif kualitatif terhadap dokumen dan hasil wawancara maupun observasi. Data kemampuan guru diambil dari isian angket dan wawancara guru setiap akhir siklus. Data guru dianalisis secara deskriptif kualitatif dengan kategori kemampuan guru sebagai berikut:

$$
\begin{array}{ll}
0 \%-25 \% & : \text { Sangat Rendah } \\
26 \%-50 \% & : \text { Rendah } \\
51 \%-75 \% & : \text { Tinggi } \\
76 \%-100 \% & : \text { Sangat Tinggi }
\end{array}
$$

Penelitian ini dilaksanakan dengan menggunakan desain penelitian tindakan sekolah, yang dirancang melalui 3 siklus dengan masing-masing siklus melalui langkah-langkah: perencanaan, pelaksanaan, pengamatan, dan refleksi. Langkah-langkahnya dapat digambarkan sebagai berikut:

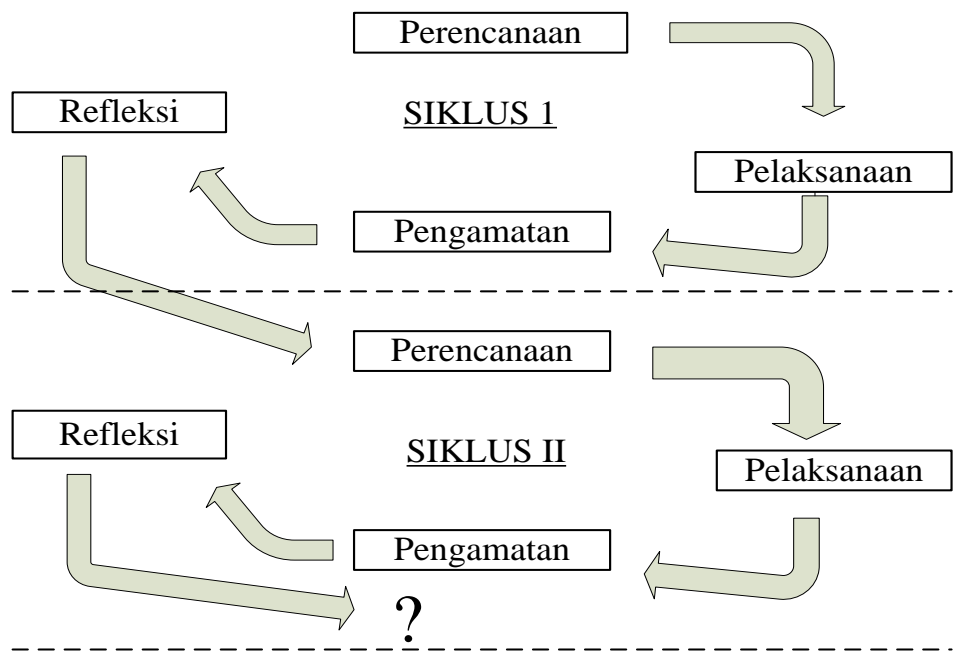

Gambar 2. Langkah-langkah PTS (Direktorat Tendik, 2010)

\section{Hasil Penelitian dan Pembahasan}


Sebelum dilaksanakan penelitian, peneliti menyebarkan angket yang bertujuan untuk mengetahui kondisi awal guru-guru SMP Negeri 23 Pontianak. Dalam angket, peneliti menanyakan tentang pemahaman dan pelaksanaan pendekatan kontekstual, serta menanyakan tentang pelaksanaan penelitian tindakan kelas yang pernah dilakukan oleh guru SMP Negeri 23 Pontianak. Jumlah guru yang mengisi angket sebelum penelitian berjumlah 21 orang. Dari 21 guru tersebut terdapat 10 guru yang belum melaksanakan pendekatan kontekstual, dengan alasan belum paham tentang pendekatan kontekstual. Dari hasil angket tersebut juga ditemukan bahwa ada 19 guru yang belum pernah melaksanakan penelitian tindakan kelas, hanya ada 2 guru yang pernah melaksanakan penelitian tindakan kelas.

Berdasarkan hasil angket tersebut, peneliti sekaligus sebagai kepala SMP Negeri 23 Pontianak, merancang kegiatan MGMP di SMP Negeri 23 Pontianak. Kegiatan ini dimaksudkan untuk mengatasi rendahnya kemampuan guru dalam membuat penelitian tindakan kelas dan mengatasi rendahnya pemahaman tentang pendekatan kontekstual. Perancangan kegiatan MGMP juga diharapkan dapat menjadikan suatu forum atau wadah profesional guru di suatu sekolah. Tujuan diselenggarakannya MGMP ini antara lain, untuk melakukan pemahaman tentang penelitian tindakan kelas, dan memantapkan guru dalam menerapkan pendekatan kontekstual. Selain itu diharapkan juga dapat memotivasi guru guna meningkatkan kemampuan dan keterampilan dalam merencanakan, melaksanakan, dan membuat evaluasi program pembelajaran dalam rangka meningkatkan keyakinan diri sebagai guru profesional. Mengingat pelaksanaan proses pembelajaran di SMP Negeri 23 Pontianak berlangsung pada siang hari, maka agar MGMP tidak mengganggu pembelajaran siswa, peneliti sekaligus sebagai kepala sekolah melaksanakannya setiap hari Jumat pagi sampai menjelang waktu sholat Jumat.

Berdasarkan pengakuan dari beberapa guru, MGMP sangat memberi manfaat bagi guru, antara lain: (1) sebagai wadah yang efektif untuk menyelesaikan permasalahan yang dihadapi oleh guru, (2) sebagai wadah untuk berdiskusi, berbagi pengalaman, dan mencari solusi permasalahan yang dihadapi oleh guru, (3) sebagai wadah yang memberikan peluang kepada guru untuk merancang program kegiatan untuk meningkatkan profesionalismenya.

Peneliti mengawali penelitian tindakan sekolah, dengan melakukan persiapan penelitian tindakan kelas untuk guru, selama 2 pertemuan. Pertemuan pertama dilaksanakan tanggal 7 September 2012. Dalam pertemuan ini peneliti menyampaikan hasil angket. Dari hasil angket tersebut diinformasikan bahwa guru-guru SMP Negeri 23 Pontianak perlu ditingkatkan kemampuannya dalam membuat penelitian tindakan kelas. Pemahaman 
tentang pendekatan kontekstual bagi guru-guru SMP Negeri 23 Pontianak juga perlu ditingkatkan. Oleh karena itu peneliti menawarkan kepada guru-guru SMP Negeri 23 Pontianak, untuk melakukan penelitian tindakan kelas secara kolaboratif. Masalah yang di atasi oleh masing-masing guru adalah tentang motivasi belajar siswa. Motivasi belajar siswa tersebut diharapkan dapat ditingkatkan melalui pendekatan kontekstual. Masalah dan judul penelitian yang dilakukan oleh guru tersebut, hampir sama yaitu meneliti tentang peningkatan motivasi belajar siswa melalui pendekatan kontekstual. Judul penelitian yang dilakukan oleh masing-masing guru hanya berbeda mata pelajaran dan berbeda kelas.

Pada pertemuan pertama dalam persiapan pelaksanaan penelitian tindakan kelas bagi guru ini, peneliti menyampaikan pemahaman tentang penelitian tindakan kelas. Peneliti membagikan hand out tentang teori penelitian tindakan kelas, dan mempresentasikannya dalam power point. Langkah berikutnya peneliti memberikan contoh proposal dan laporan penelitian tindakan kelas yang pernah dibuat oleh peneliti kepada para guru. Pada pertemuan ini peneliti mengkhususkan menyampaikan tentang Pendahuluan dalam Bab. I, yang berisi: Latar Belakang, Identifikasi Masalah, Pembatasan Masalah, Rumusan Masalah, Tujuan Penelitian, dan Manfaat Hasil Penelitian. Pada akhir pertemuan para guru diberi tugas rumah untuk membuat isi Bab I, yang diharapkan sudah selesai dibuat pada pertemuan berikutnya.

Pertemuan kedua dalam persiapan penelitian tindakan kelas oleh guru, dilaksanakan tanggal 14 September 2012. Pada awal pertemuan kedua ini peneliti menanyakan kepada guru yang hadir, tentang tugas rumah yang sudah dibuat apakah ada hambatan atau kendala. Ada beberapa guru masih ada yang menanyakan tentang judul penelitian dan kemudian merevisi judul penelitiannya. Langkah berikutnya pada pertemuan ini adalah membuat dan menyepakati lembar observasi. Kemudian dilanjutkan dengan menentukan pasangan peneliti dan observer, serta menentukan jadwal pelaksanaan penelitian. Akhir pertemuan kedua ini guru diberi tugas rumah untuk membuat Bab II, seperti contoh yang sudah dibagikan. Pertemuan berikutnya diharapkan semua guru sudah mendapatkan hasil penelitian tindakan kelas berupa hasil obervasi pertemuan ke-1 pada siklus pertama

\section{Kegiatan Siklus I}


Siklus pertama ini terdiri dari 3 pertemuan, yaitu tanggal 21 dan 28 September 2012, serta tanggal 5 Oktober 2012, dengan langkah-langkah sebagai berikut:

1. Perencanaan.

Sebelum mulai siklus I diharapkan peserta MGMP sudah selesai membuat bab I dan bab II. Dalam siklus ini, disamping peserta sudah mulai melaksanakan penelitian, juga diberi tugas untuk membuat bab III, sesuai dengan panduan yang sudah diberikan oleh peneliti.

2. Pelaksanaan

a. Pertemuan tanggal 21 September 2012.

Pada pertemuan pertama siklus 1 ini diawali dengan membahas tugas rumah yang sudah dibuat oleh masing-masing guru tentang Bab II yang berisi Tinjauan Pustaka. Kajian teori yang diambil adalah tentang teori motivasi dari Suryabrata (1984) dan Brown (1971). Sedangkan kajian teori tentang pendekatan kontekstual diambil dari Zahorik (1995).

Peneliti sekaligus sebagai nara sumber pada pertemuan ini mendapatkan tiga pertanyaan dari para guru sebagai berikut:

Guru EP : Bagaimana kalau judulnya mencantumkan materi?

Peneliti : Boleh saja asalkan materi tersebut cakupan materinya luas, artinya memerlukan waktu yang cukup dipakai untuk penelitian tindakan kelas. Karena kita harapkan dalam penelitian ini minimal 2 siklus, dan setiap siklus minimal 3 pertemuan. Sehingga kalau materi tersebut disampaikan minimal 6 pertemuan, maka pencantuman materi dalam judul penelitian akan terpenuhi. Apabila materi tersebut tidak dapat disampaikan minimal 6 pertemuan, sebaiknya judul tidak mencantumkan materi, tetapi cukup nama mata pelajarannya saja.

Guru NN : Bagaimana cara membuat laporan?

Peneliti : Bab I, II, dan III dalam proposal yang menggunakan kata akan dilakukan, diganti dengan telah dilakukan. Bab IV, diisi dengan temuan-temuan, utamanya yang ditemukan oleh observer, serta tindakan-tindakan yang dilakukan oleh peneliti. Bab V, nanti diisi dengan kesimpulan dan saran. Bagian awal antara lain diisi dengan kata pengantar, daftar isi, lembar pengesahan, abstrak. Bagian akhir dilampirkan, antara lain RPP yang sesuai dengan tindakan yang dilakukan, lembar observasi, dan lain-lain. 
Guru FM : Apakah dalam CTL, selalu mengaitkan dalam kehidupan sehari-hari?

Peneliti : Pendekatan kontekstual, dianjurkan pendekatan pada proses pembelajaran. Dalam pendekatan kontekstual meliputi 7 pilar: kontrukivisme, inquiry, questioning, learning community, modeling, reflection, dan authentic assessment. Sehingga pendekatan kontekstual dapat dilakukan untuk semua materi pelajaran. Tetapi jika yang dimaksud setiap materi harus dikaitkan dalam kehidupan sehari-hari, maka tidak semua materi dapat dengan mudah dikaitkan dalam kehidupan sehari-hari. Sebagai contoh pada pelajaran matematika tentang pangkat tak sebenarnya, maka akan sulit untuk mengaitkan dalam kehidupan sehari-hari. Jadi pendekatan kontekstual adalah pendekatan pada proses pembelajaran, bukan pada materi ajarnya.

b. Pertemuan tanggal 28 September 2012.

Pada pertemuan ini diawali dengan memberi kesempatan kepada guru untuk menyampaikan pertanyaan, komentar atau temuan-temuan pada penelitian yang sedang dilakukan.

Guru TT : Bagaimana kalau observernya ada halangan, apakah dapat diteruskan penelitiannya.

Peneliti : Tetap dilanjutkan, peneliti boleh sekaligus sebagai observer. Tetapi penekanannya adalah kejujuran. Apapun yang terjadi dicatat apa adanya, tidak boleh direkayasa.

Guru FM : Boleh tidak kalau pertemuan berikutnya hasilnya menurun.

Peneliti : Kalau hasilnya menurun, kita pikirkan lagi apakah tindakan yang sudah dilakukan sudah maksimal. Kita minta masukan dari observer, kita cari penyebab mengapa turun, kemudian pada pertemuan berikutnya kita beri tindakan tambahan sehingga menjadi meningkat. Beginilah salah satu ciri penelitian tindakan kelas, setiap akhir pertemuan selalu dilakukan refleksi, agar selalu dapat dilakukan tindakan yang tepat untuk meningkatkan mutu proses pembelajarannya.

Guru ML : Boleh tidak, jika identifikasi masalahnya tentang moral.

Peneliti : Dalam penelitian tindakan kelas, yang diteliti atau diamati adalah tentang proses pembelajarannya. Apabila materinya tentang moral siswa atau moral bangsa, maka 
yang diteliti adalah bagaimana meningkatkan moral siswa tersebut. Dengan cara apa untuk meningkatkannya, dimana dan siapa yang ditingkatkan moralnya.

Guru SF : Bagaimana jika penelitiannya tentang materi pelajaran, karena ada yang berpendapat bahwa kalau yang diteliti tentang motivasi terlalu luas.

Peneliti : Dianjurkan dalam penelitian tindakan kelas yang diteliti adalah proses menyampaikan materi pelajaran, atau caracara menyampaikan materi pelajaran agar hasilnya meningkat. Apa bila prosesnya baik diharapkan hasilnya juga akan baik. Dalam penelitian tindakan kelas, yang ditingkatkan tidak harus motivasinya. Tetapi kalau meningkatkan motivasi dipandang terlalu luas, maka kita boleh memberi batasan-batasan pengertian motivasi dalam penelitian yang dilakukan. Seperti kita katakan bahwa dalam penelitian ini yang dimaksud oleh peneliti tentang motivasi adalah segala sesuatu yang menyebabkan siswa menyenangi atau menyukai pelajaran tertentu.

Guru GK : Bagaimana kalau dalam penelitian ini materinya berat atau sulit.

Peneliti : Materi pelajaran yang dianggap berat atau sulit, akan sangat baik kalau diteliti. Dengan diteliti diharapkan akan ditemukan tindakan-tindakan yang cocok untuk menyampaikan materi yang sulit sehingga akan menjadi mudah. Salah satu cara adalah dengan menggunakan alat peraga, alat praktik, atau dengan cara-cara lain yang dapat mempermudah pemahaman siswa.

Setelah selesai tanya jawab dengan peserta MGMP, peneliti membagikan contoh laporan penelitian bab III. Bab ini memuat: setting penelitian, metode penelitian, metode pengumpulan data, dan analisis data. Pada akhir pertemuan ini para guru diberi tugas untuk membuat bab III, dan pertemuan berikutnya diharapkan sudah selesai.

c. Pertemuan tanggal 5 Oktober 2012

Peneliti memberi kesempatan kepada guru untuk menanyakan hambatan atau kesulitan dalam membuat bab III. Salah satu guru menanyakan tentang judul bab III, yang betul Metodologi Penelitian 
atau Metode Penelitian. Peneliti menginformasikan bahwa keduanya tidak salah, pilih salah satu saja dan peneliti meminta salah satu pasangan kolaborasi untuk menyampaikan hasil observasinya, (1) pasangan guru ND dan ES mempresentasikan hasil pengamatannya. Guru ND menanyakan solusi, apabila materi ajarnya sulit, ternyata beberapa anggota kelompok menjadi ribut. Beberapa guru yang lain menanggapi, antara lain meminta materinya disederhanakan dulu atau dijelaskan menggunakan bantuan alat peraga yang di sampaikan oleh guru. (2) pasangan guru SP dan SF mempresentasikan hasil observasinya. Kedua guru tersebut menyatakan bahwa dengan penelitian tindakan kelas ternyata dapat mempermudah dalam melaksanakan pembelajaran dan siswa lebih aktif dan tertib.

3. Obeservasi

Peserta MGMP saling berkolaborasi dengan guru sejenis, dan saling melakukan pengamatan bergantian sesuai dengan jadwal yang sudah dibuat.

4. Refleksi

Hasil pengamatan peserta MGMP, masing-masing di bahas pada setiap Jumat mulai pukul 07.30 sampai selesai, di pimpin oleh peneliti.

\section{Kegiatan Siklus II}

1. Perencanaan.

Pada siklus ini diharapkan peserta MGMP sudah selesai membuat bab III, sesuai panduan yang sudah diberikan peneliti. Dalam siklus ini peserta diperkenankan meminta bantuan peneliti setiap saat apabila mengalami hambatan dalam membuat bab I, Bab II, dan bab III. Setiap jumat sesuai dengan jadwal yang sudah ditentukan, peneliti dan peserta mengadakan pertemuan untuk membahas bersama kesulitan dan hambatan yang ditemukan selama penelitian serta peserta melakukan simulasi hasil pengamatannya.

2. Pelaksanaan

a. Pertemuan tanggal 12 Oktober 2012.

Pertemuan diawali dengan memberi kesempatan kepada guru, untuk menyampaikan hambatan atau temuan-temuan yang perlu di bahas bersama.

Guru LM : Saya mengalami kesulitan mencari observer. Kalau saya sendiri sebagai observer dan sekaligus sebagai peneliti, maka tidak ada masukan untuk perbaikan.

Peneliti : Observer tidak harus dari satu mata pelajaran, tetapi yang penting harus disiapkan lembar observasi yang dapat 
dipahami. Masukan untuk perbaikan boleh meminta pertimbangan atau masukan kepada yang dianggap kompeten. Seperti pada pertemuan ini, dapat digunakan untuk membantu menyelesaikan masalah-masalah yang ada.

Guru FM : Saya mencoba melakukan praktik menemukan rumus luas bola, anak sudah diberi tahu untuk membawa bahanbahannya, ternyata tidak semua anak membawanya. Dari 7 kelompok hanya 4 kelompok yang membawa. Karena pinjam sana, pinjam sini maka kelas jadi ribut, bagaimana solusinya?

Peneliti : Kalau terjadi lagi seperti itu, maka perlu dicoba dengan memasukkan kelompok yang tidak membawa bahan praktik ke kelompok yang sudah siap. Salah satu anggota kelompok mendemonstrasikan atau mempraktikan pertahap, anggota yang lain mencatat hasil pengamatan dan kemudian mendiskusikan hasilnya. Atau dapat juga salah satu kelompok yang dianggap paling lengkap bahannya mendemonstrasikan di depan kelas dengan bimbingan guru, dan kelompok yang lain menyimak dan mencatat data yang di dapat kemudian mendiskusikan dengan anggota kelompoknya.

Guru RP : Bagaimana refleksi dalam mata pelajaran olah raga, dan bagaimana kalau peralatan untuk praktik kurang.

Peneliti : Misalkan dalam passing bola, dalam merefleksi guru dapat mengulang kembali dengan memperagakan cara passing yang benar. Alat praktik olah raga kalau belum ada, bisa diatasi dengan meminta siswa membawa dari rumah alat praktik yang ada, atau dapat menggunakan alat yang sejenis. Misalnya kalau belum ada bola volly, maka dapat menggunakan bola plastik yang mudah didapat.

Guru FM : Bagaimana untuk mengatasi upaya meningkatkan hasil belajar dapat maksimal, padahal pada saat belajar siswa banyak paham, namun waktu di tes hasilnya tidak maksimal.

Peneliti : Apabila proses pembelajarannya semakin baik, diharapkan hasil belajarnya juga semakin baik. Apabila ternyata hasil belajar atau hasil ulangan menurun atau tidak maksimal, maka perlu diteliti penyebabnya. Perlu diteliti kembali apakah soalnya sesuai dengan kisi-kisi yang sudah dibuat, 
atau ada penyebab lain. Soal ulangan diharapkan, berasal dari mengulang materi yang pernah disampaikan dalam pembelajarannya. Sedangkan soal ujian, dibuat dari pendalaman, pengembangan atau aplikasi materi yang pernah diajarkan. Sehingga soal ulangan idealnya dapat mencapai KKM.

Guru ER : Bagaimana dalam pelajaran IPA, siklus pertama 3 pertemuan kemudian pada pertemuan keempat ganti materi.

Peneliti : Dalam penelitian tindakan kelas tidak harus satu materi. Materinya berkelanjutan, penelitian tindakan kelas materi yang diajarkan di kelas tidak diulang-ulang, tetapi berkelanjutan mengikuti materi yang ada di silabus pembelajaran, mengikuti program semester yang sudah dibuat.

Pada akhir pertemuan dilakukan simulasi pasangan kolaborasi guru ES dan guru TR. Dari simulasi ini ditemukan halhal berikut: (1) dalam tahap inquiri siswa mengalami kesulitan menemukan pokok-pokok berita, (2) kesulitannya di unsur mengapa, (3) siswa yang merespon sedikit, (4) karena pada waktu pembelajaran sedang hujan lebat, sehingga proses pembelajaran terganggu, sehingga tidak maksimal, (5) ada satu pasangan agak pasif dan siswa sebagian besar belum berani mengemukakan pendapat, (6) guru sudah memberi penguatan dengan baik

b. Pertemuan tanggal 19 Oktober 2012.

Pada pertemuan ini dibahas masalah dan temuan-temuan yang dijumpai oleh guru.

Guru WW : Minggu depan rencana saya akan sampai pertemuan ke 5 dan 6 , tetapi ada panggilan untuk mengikuti pelatihan, bagaimana solusinya?

Peneliti : Ikuti panggilan pelatihan dan penelitian dilanjutkan setelah selesai mengikuti pelatihan. Tugas kepada siswa selama mengikuti pelatihan di berikan kepada guru piket atau minta tolong guru sejawat untuk menggantikannya.

Guru PN : Saya sudah selesai siklus pertama, dan sudah menyebarkan angket motivasi belajar. Dari hasil angket setelah saya rangkum ternyata motivasi belajar IPA bagus, tetapi setelah dilakukan ulangan, ternyata hasilnya kurang memuaskan, bagaimana solusinya? Beberapa siswa sempat saya wawancarai, mengapa hasil 
ulangannya jelek, apakah tidak belajar. Beberapa siswa menjawab, karena masuk siang sehingga pulang sekolah sudah malam dan capek, sehingga tidak belajar. Disamping itu saya sempat mengecek buku catatan IPA, ternyata banyak siswa tidak mencatat ringkasan yang saya tulis di papan tulis.

Peneliti : Ibu sudah bagus, sudah mencari penyebabnya, siswa tidak dapat belajar setelah pulang sekolah karenaa sudah capek. Boleh disarankan kepada siswa, karena masuk siang maka belajar di rumah pada waktu pagi sebelum masuk sekolah. Kalau tidak sempat mencatat ringkasan di papan tulis, dianjurkan siswa memiliki buku referensi, dan hal-hal yang penting dapat ditandai dengan stabilo.

Guru ER : Saya sudah selesai siklus pertama, dalam rencana saya pertemuan ke- 5 dan ke-6 berbeda materi dengan pertemuan ke-7 dan ke-8, tetapi pertemuan tersebut saya jadikan satu siklus, bagaimana sebaiknya?

Peneliti : Berarti siklus 2 adalah pada pertemuan 5, 6, 7, dan 8 . Berbeda materi dalam satu siklus dibolehkan, karena yang diteliti adalah proses pembelajarannya, bukan materinya. Yang penting diupayakan adalah tindakantindakan pada siklus pertama tadi dipertahankan, dan ditambah tindakan baru lagi yang di anggap dapat meningkatkan proses pembelajarannya.

Guru EA : Saya sudah menyebar angket untuk mengetahui motivasi belajar siswa, ternyata ada siswa yang jujur mengatakan tidak senang dengan mata pelajaran yang saya ajarkan, bagaimana solusinya?

Peneliti : Siswa tersebut dapat diwawancarai dengan hati-hati. Dekati dan berikan motivasi, berkata jujur sangat bagus. Kejujuran ini modal utama untuk wawancara, dicari penyebab-penyebab siswa tersebut tidak menyukai pelajaran. Siswa tersebut kita beri perhatian lebih, agar motivasi belajar pada mata pelajaran tersebut dapat meningkat. Semoga berhasil.

c. Pertemuan tanggal 2 Nopember 2012.

Pertemuan ini adalah akhir siklus II, peneliti menanyakan kemajuan masing-masing peserta, dan memberi kesempatan kepada peserta 
untuk menanyakan hambatan dan temuan-temuan selama penelitian. Hasilnya sebagai berikut:

GR : sudah selesai siklus I, bagaimana langkah selanjutnya?

Peneliti : tindakan yang sudah berhasil dapat dilanjutkan, kemudian ditambah tindakan lain yang dapat meningkatkan proses belajar.

TW : sudah selesai siklus I, akan melanjutkan ke siklus II

Peneliti : lanjutkan.

EN : sudah selesai siklus I, dan sudah melakukan tes serta menyebar angket, tetapi belum direkap.

Peneliti : silakan direkap, dan lanjutkan dengan pertemuan berikutnya, memasuki siklus II.

DS : baru melaksanakan 2 pertemuan, karena mengikuti pelatihan, apakah boleh dilanjutkan?

Peneliti : lakukan 1 pertemuan lagi untuk menyelesaikan siklus I, kemudian lanjutkan dengan siklus II.

FM : sudah selesai siklus II, angket akhir siklus belum direkap.

Peneliti : bandingkan hasilnya antara siklus I dan siklus II, kalau sudah meningkat boleh berhenti atau lanjutkan ke siklus III, supaya lebih meningkat.

WW : sama dengan FM, sudah selesai siklus II. Saya membuat soal tes untuk akhir siklus, apakah harus divalidasi dan bolehkan soal tersebut diujikan ke kelas lain?

Peneliti : Sebaiknya soal divalidasi, dan soal yang sudah divalidasi ternyata baik, maka boleh digunakan dikelas lain. Dalam penelitian tindakan kelas yang penting adalah peningkatan proses pembelajaran. Kalau proses pembelajaran meningkat, diharapkan hasil tesnya juga meningkat.

WN : sudah selesai siklus I, dan akan melakukan tes, apakah soal tes nanti dilampirkan dalam laporan penelitian?

Peneliti : semua bukti fisik dalam penelitian, sebaiknya dilampirkan, untuk memperkuat bukti keaslian penelitian.

ER : Hasil rekap siklus I ternyata prosentase motivasi terlalu rendah, bagaimana solusinya?

Peneliti : mencari tindakan tambahan, yang memungkinkan untuk meningkatkan motivasi, misalnya dengan melakukan wawancara kepada siswa yang motivasi belajarnya rendah. Ditanya kepada siswa apa keinginannya supaya senang belajar, bagaimana ia belajar dan apa kesuliatan atau hambatan dalam belajar. 
SP : Hasil siklus I dan II sudah direkap. Motivasi siklus I sebesar 78\%, sedangkan pada siklus II motivasinya 98\%, apakah dilanjutkan pada siklus III?

Peneliti : Berarti peningkatan motivasi dari siklus I ke siklus II sebesar 20\%. Boleh berhenti sampai siklus II saja, atau dapat dilanjutkan ke siklus III, sehingga sampai $100 \%$. Kemudian dilanjutkan laporannya ke bab V.

3. Observasi

Pengamatan yang dilakukan oleh masing-masing peserta MGMP dan pengamatan peneliti terhadap semua peserta MGMP menjadi bahan data yang akan diolah dalam penelitian ini.

4. Refleksi

Refleksi dilakukan setiap hari jumat sesuai dengan jadwal yang sudah ditentukan. Peserta melakukan simulasi hasil pengamatannya, dan dibahas bersama tindakan-tindakan yang perlu dipertahankan, dan memperbaiki atau menambah tindakan baru, agar mutu pembelajarannya meningkat.

Pada akhir siklus II dibagikan angket.

\section{Kegiatan siklus III}

1. Perencanaan.

Pertemuan ini adalah awal dari siklus III. Pada awal siklus ini diharapkan semua peserta MGMP sudah selesai membuat bab I, bab II, dan bab III. Peserta MGMP diberi tugas untuk mengolah hasil peneltian dan pembahasannya, seperti contoh dan penjelasan peneliti pada waktu persiapan penelitian.

2. Pelaksanaan

a. Pertemuan tanggal 9 September 2012

Pada awal pertemuan ini peneliti memberi kesempatan kepada semua peserta MGMP untuk menyampaikan temuan dan hasil penelitian yang sudah dilakukan, sebagai berikut:

Guru FM : Hasil siklus I dan siklus II sudah direkap, motivasi belajar pada siklus I sebesar $71,43 \%$, sedangkan pada siklus II sebesar $84,85 \%$. Hasil belajar pada siklus I rata-rata 29,82 dan pada siklus II hasil belajar rata-rata 56,56 . Bagaimana langkah selanjutnya?

Peneliti : Berarti peningkatan motivasi belajar dari siklus I ke siklus II sebesar $13,42 \%$ dan hasil belajarnya mengalami kenaikan 26,74. Dilihat dari motivasi belajar sudah bagus, hasil belajar juga mengalami kenaikan, 
namun dilihat dari hasil belajar, nampaknya masih banyak siswa yang belum tuntas, perlu dianalisis hasil belajar dan analisis butir soal, apakah soalnya banyak yang sulit ataukah ada hal lain yang menyebabkan hasil belajarnya masih rendah.

Guru WW : Pada siklus I ke siklus II, sudah dibandingkan hasilnya motivasi belajar dan hasil belajar ternyata keduanya meningkat. Namun ada pertanyaan, kriteria keberhasilan belajar apakah selalu mengacu pada KKM?

Penelti : Walaupun dari siklus I ke siklus II sudah meningkat, namun peningkatannya belum sesuai dengan target yang diingingkan, maka boleh dilanjutkan ke siklus ke III. KKM bukan merupakan kriteria keberhasilan belajar, tetapi KKM merupakan Kriteria Ketuntasan Minimal. KKM merupakan target minmal yang dicapai oleh siswa. Kita menginginkan keberhasilan secara maksimal, sehingga kalau siswa sudah mencapai KKM bukan berarti kita sudah berhasil. Kita harus berusaha mencapai secara maksimal, bukan minimal.

Guru SF : Baru selesai siklus I, dan hasilnya sudah di rekap. Motivasi belajar siswa mencapai $81,03 \%$ dan hasil belajar siswa rata-rata mencapai 73,18. Akan melanjutkan siklus II sebanyak 5 pertemuan, apakah dibolehkan, dan bagaimana jika dalam siklus II nanti ada siswa yang tidak meningkat motivasi belajarnya?

Peneliti : Dalam satu siklus sebaiknya minimal 3 pertemuan, yang penting tindakan dalam siklus tersebut betul-betul dapat mewarnai pembelajaran sehingga dapat meningkatkan mutu proses pembelajaran dan dapat meningkatkan hasil belajar.

b. Pertemuan tanggal 23 September 2012

Pada pertemuan ini peneliti memberi kesempatan kepada peserta untuk menyampaikan temuan dan masalah yang dihadapi.

Guru GR : Siklus I motivasi belajar 88\% dan siklus II motivasi belajar hanya 89\%. Naiknya sedikit sekali. Apakah dilanjutkan siklus III?

Peneliti : Motivasi belajar sudah termasuk kategori bagus, hanya peningkatannya baru sebesar $1 \%$. Kita pertemuan 
bersama tinggal satu kali lagi yaitu minggu depan, sehingga siklus III tidak mungkin dilaksanakan, karena sudah ulangan umum. Oleh karena itu penelitian sampai siklus II, kemudian didalam bab V dituliskan dalam saran agar kekurangan-kekurangan dapat diteruskan ke peneliti berikutnya.

Guru EN : Alhamdulilah motivasi belajar siswa dari siklus I ke siklus II naik dari 59\% menjadi $85 \%$. Hasil belajar naik dari rata-rata 60 menjadi 73. Saya lakukan sesuai saran bapak (peneliti). Terimakasih.

Peneliti : Berarti sampai siklus II saja, karena minggu berikutnya sudah persiapan ulangan umum. Kemudian silahkan dilanjutkan dengan membuat laporan penelitian secara lengkap. Bukti fisik semua dilampirkan.

c. Pertemuan tanggal 14 Desember 2012

Pada pertemuan ini digunakan untuk membuat grafik hasil penelitian, membandingkan hasil siklus I, siklus II, dan siklus III. Dilanjutkan dengan membahas bab V serta bukti fisik yang harus dilampirkan.

3. Observasi

Peneliti melakukan observasi dengan mengamati langsung kepada setiap peserta MGMP didalam pelaksanaan mengajar di kelas dan pembuatan laporannya. Peneliti juga berdiskusi dengan guru yang mengamati dikelas.

4. Refleksi

Refleksi dilakukan oleh masing-masing peserta MGMP setelah selesai diamati, dan secara keseluruhan dibahas bersama setiap jumat sesuai dengan jadwal yang sudah ditentukan.

\section{Pembahasan tiap siklus, dan antar siklus,}

Kemampuan guru melakukan penelitian tindakan kelas pada siklus I yang sedang dilaksanakan guru-guru SMP Negeri 23 Pontianak sebesar $38,82 \%$ dalam kategori rendah. Sedangkan hasil rekap jawaban pertanyaan nomor 10 adalah sebagai berikut: (1) Masih bingung juga, karena bobot materi yang disampaikan saat penelitian berbeda-beda, jadi reaksi anak juga berbedabeda, (2) Masih bingung karena baru pertama kali melakukan penelitian, (3) Kesulitan merangkai kata-kata untuk menulis, (4) Hambatan: kadang-kadang 
lupa dengan persiapan penelitian, (5) Belum terbiasa melakukan PTK, (6) Selalu mau belajar dan belajar terus menerus, (7) Dalam merangkai bahasa menjadi bacaan belum pandai, (8) Saya merasa penelitian ini jadi beban berat buat saya karena keterbatasan waktu dan ilmu yang saya miliki. Terlalu banyak tuntutan yang harus dipenuhi, sementara tugas mengajar pun saya merasa belum maksimal. Saya pesimis belum mampu membuat laporan tertulis yang bagus, apa dampaknya buat saya? Apalagi PTK ini tidak harus dilakukan oleh semua guru, jelasnya ada yang melaksana kan ada juga yang tidak, (9) Belum terbiasa diobservasi.

Untuk mengatasi hambatan dan kesulitan dalam melakukan penelitian tindakan kelas tersebut diatas, maka dilakukan bimbingan lebih intensif oleh kepala sekolah yang sekaligus sebagai peneliti dalam penelitian tindakan sekolah pada siklus II. Disamping melakukan refleksi umum di setiap jumat siang, kepala sekolah juga melakukan bimbingan pada waktu istirahat belajar.

Setelah selesai siklus II, disebarkan angket seperti pada akhir siklus I. Dari hasil rekap diatas kemampuan guru melakukan penelitian tindakan kelas pada sikulus II yang sedang dilaksanakan guru-guru SMP Negeri 23 Pontianak adalah 78,33\% dalam kategori sangat tinggi. Sedangkan hasil rekap jawaban pertanyaan nomor 10 adalah sebagai berikut: (1) Hambatan dan kesulitan saya yaitu keterbatasan waktu untuk membuat laporan PTK, (2) Ada siswa yang tidak kooperatif, (3) Membuat grafik, dan waktu untuk menentukan observer kita kadang jam yang kurang pas, (4) Masih belum konsentrasi dalam menyusun laporan karena membuat tugas yang lain, (5) Observer guru bidang studi Bahasa Inggris tidak menemui waktu yang sesuai untuk melakukan observasi. Saya kurang pandai memanage waktu sehingga mengerjakan PTK ini terbelangkai, (6) Tidak konsentrasi dalam pembelajaran sore hari, (7) Observer dan peneliti mengajar di jam yang sama, sehingga penelitian harus menunggu observer yang tidak mengajar, (8) Kesulitan menemukan cara jitu untuk memotivasi beberapa orang siswa yang nakal, (9) Saran: tetap membuat PTK untuk perbaikan dalam mengajar. Hambatan/ kesulitan: Waktu dirumah biasa tidak sempat menuliskan kerja/ menulis PTK, (10) Menentukan beberapa pertemuan untuk satu kali siklus, (11) Saran: dengan adanya PTK semua guru SMP Negeri 23 Pontianak, lebih baik dan bersinergi untuk mengajar ke depannya, (12) Masih kurangnya sarana dan prasarana olah raga, sehingga setiap praktik harus selalu menggunakan alat yang di modifikasi, (13) Saya belum memahami cara mengolah data dan menganalisis data sehingga penelitian saya sementara mentok di Bab III, (14) Untuk mencoba menggunakan metode yang berbeda dalam kegiatan pembelajaran perlu waktu, media pembelajaran yang sering/ kadang-kadang tidak dapat disiapkan sehingga ringkasnya selalu menggunakan metode yang sama yang 
menyebabkan siswa kurang termotivasi, (15) Melakukan persiapan penelitian supaya motivasi belajar dan hasil belajar meningkat, (16) Kesulitannya dalam pengetikan saya masih tahap belajar menggunakan laptop, (17) Hambatan saya di dalam melakukan penelitian ini masih ada rasa segan untuk minta diajarkan dengan guru lain karena terkadang melihat mereka sibuk dengan kerjaaannya, terutama dalam merekap, mengolah dan menganalisis data.

Untuk mengatasi hambatan dan kesulitan tersebut diatas, maka pada siklus III kepala sekolah sebagai peneliti tindakan sekolah melakukan bimbingan persuasif kepada beberapa guru yang dianggap masih belum maksimal dalam melakukan penelitian, dengan memberi contoh-contoh laporan penelitian tindakan yang sudah ada.

\section{Perbandingan antar siklus I dan siklus II}

Prosentase jumlah guru SMP Negeri 23 Pontianak yang sudah mampu melakukan penelitian tindakan kelas pada siklus I sampai siklus II dituangkan dalam tabel sebagai berikut:

\begin{tabular}{|c|c|c|}
\hline \multirow{2}{*}{ Siklus } & \multicolumn{2}{|c|}{ Prosentase } \\
\cline { 2 - 3 } & Sudah Mampu & Belum Mampu \\
\hline I & 38,82 & 61,18 \\
\hline II & 78,33 & 21,67 \\
\hline Selisih & \multicolumn{2}{|c|}{39,51} \\
\hline
\end{tabular}

Tabel 1: Perbandingan siklus I dan II

Dari tabel tersebut dapat disimpulkan bahwa kemampuan guru SMP Negeri 23 Pontianak dalam melakukan penelitian tindakan kelas dari siklus I ke siklus II mengalami kenaikan sebesar 39, $51 \%$. Data ini dapat dituangkan dalam grafik sebagai berikut: 


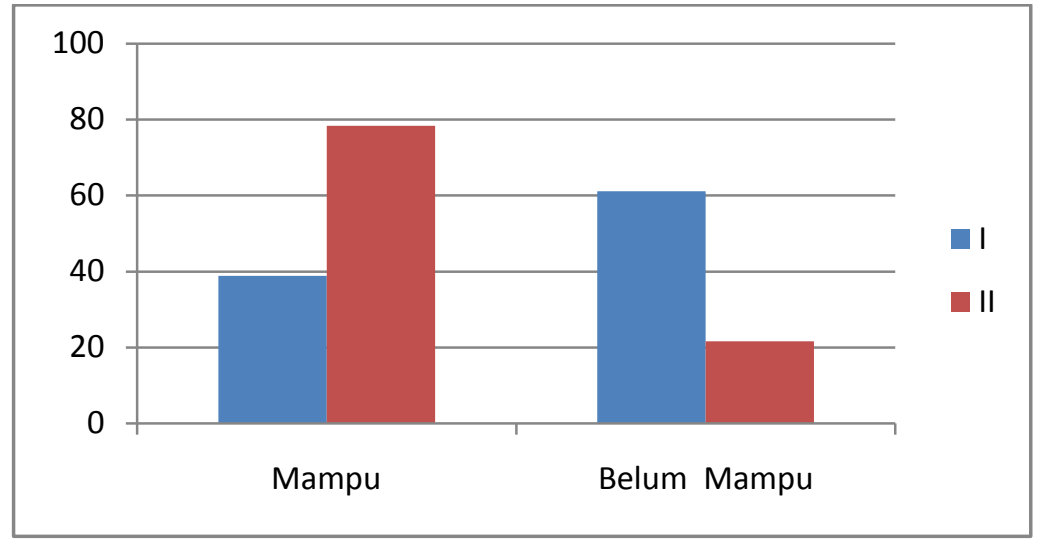

Grafik 1: Perbandingan antara siklus I dan II

Pada akhir siklus III diberikan angket dengan 3 pertanyaan. Angket ini hanya diberikan kepada peserta MGMP yang tidak selesai atau kurang aktif dalam mengikuti MGMP sekolah. Hasilnya direkap sebagai berikut:

a. Jawaban pertanyaan No.1: (1) Sangat baik, banyak manfaat dan pelajaran yang dapat saya peroleh dalam kegiatam MGMP sekolah, (2) Sangat baik dan banyak manfaatnya, (3) Tanggapan saya, sangat baik sekali, karena menambah pengetahuan dan sangat baik sekali kita praktikkan di dalam kelas terasa enak, (4) Workshop penelitian tindakan kelas menurut saya bagus karena dari kegiatan tersebut dari yang tidak tahu menjadi tahu, (5) Pada prinsipnya saya setuju dan tertarik karena bermanfaat sekali terutama untuk meningkatkan pembelajaran dan hasil belajar anak serta kemungkinan membantu kenaikan pangkat, (6) Workshop penelitian tindakan kelas bagi saya baik/ bagus. Workshop ini menambah pengetahuan ilmu kita semua, (7) Sangat baik karena banyak pelajaran yang didapat, (8) Kegiatan workshop PTK bagus untuk melatih guru dan membiasakan guru untuk melakukan penelitian sekaligus menulis karya ilmiah, tapi pihak sekolah juga harus menyadari bahwa tiap guru mempunyai kemampuan yang berbeda, sehingga untuk bisa mengerti bila ada guru yang memang tidak siap untuk melakukan PTK.

b. Jawaban pertanyaan nomor 2: (1) Waktu MGMP ini saya masih cuti, kedepannya saya mohon bimbingan dan bantuan dalam menyusun PTK, (2) Mohon maaf saya tidak mengikuti karena alasan keluarga. Mohon bimbingan dan bantuan dalam menyusun PTK, (3) Pertama sakit. Kedua alat transportasinya ada halangan (rusak). Ketiga: waktunya yang digunakan berbenturan dengan kegiatan di tempat yang tidak bisa 
ditinggalkan, (4) Dikarenakan ibu saya sering sakit, perlu istirahat, sehingga saya bingung kalau ditinggalkan, (5) Jujur, saya ketika semester ganjil secara mental belum siap.Kapan dan bagaimana secara tepatnya untuk memulai menyusunnya (ada hambatan mata). Lain dari itu saya banyak urusan yang bertabrakan jadwal workshop yang bersifat dilema. Makanya kadang ikut, kadang tidak. Insya Allah semester genap karena sudah di jadwal di hari kerja akan ikut, (6) Saya masih bingung mengatur waktu, (7) Saya mengikuti hanya setengah perjalanan dikarenakan saya sakit dan tidak dapat berpikir, semoga di masa yang akan datang tidak ada halangan, (8) Sedang cuti sakit.

c. Jawaban pertanyaan nomor 3: (1) Saran saya supaya kegiatan-kegiatan yang sering kita laksanakan seperti workshop PTK, dan membahas masalah-masalah yang berhubungan dengan KBM, kedepannya ditingkatkan lagi, (2) Perlu pelatihan-pelatihan untuk membahas masalahmasalah yang berhubungan dengan KBM, (3) Saran saya, karena apa yang sudah dilakukan untuk meningkatkan profesionalisme guru untuk masa yang akan datang, teruskan. Dan kembali yang tidak aktif di MGMP, mungkin memang waktunya tidak bisa. Dan saya yakin tidak ada seseorang tidak mau maju, (4) Saran dan harapan saya supaya kegiatan workshop tidak dilaksanakan setiap hari jumat (dalam sebulan 3 minggu sekali atau di selang seling) atau ada hari khusus untuk kegiatan tersebut dan sarana prasarana lebih ditingkatkan lagi, (5) Silahkan lanjutkan saja program kegiatan yang telah direncanakan. Kalau boleh urun rembug, jangan lupa kami jamaah/ para dewan guru diajak diskusi/ dikoordinasikan sehingga kami rela dan tidak ada beban atau merasa terpaksa, (6) Kegiatan MGMP lebih ditingkatkan lagi, (7) Saran saya untuk alat peraga terutama papan berpetak minta diperhatikan, karena terlalu kecil dan untuk alat tulis sebisanya setiap guru diberikan agar tidak adanya keluar masuk siswa untuk mengisi spidol. Untuk meningkatkan profesionalisme, saya ingin diajarkan/ belajar lagi apa yang belum saya ketahui.

Dari 27 orang guru SMP Negeri 23 Pontianak, yang selesai melakukan penelitian tindakan kelas sebanyak 14 orang. Jumlah guru yang tidak melakukan penelitian tindakan kelas ada 4 orang. Alasan tidak ikut melakukan penelitian adalah karena sedang cuti, sakit, dan tidak dapat melakukan pertemuan setiap Jumat, diluar pembelajaran karena alasan keluarga dan kesibukan yang lain. Ada 2 guru yang hanya dapat mengikuti 1 kali pertemuan, dengan alasan ada kesibukan dirumah. Sebanyak 7 orang guru dapat mengikuti lebih dari 2 kali pertemuan tetapi tidak selesai membuat laporan (lampiran 12). Jumlah guru yang mampu mengikuti MGMP Intern 
SMP Negeri 23 Pontianak dalam membuat penelitian tindakan kelas, dapat ditunjukkan dalam tabel berikut:

\begin{tabular}{|l|c|}
\hline \multicolumn{1}{|c|}{ Kemampuan Guru } & $\begin{array}{c}\text { Jumlah Guru Melakukan Penelitian } \\
\text { Tindakan Kelas }\end{array}$ \\
\hline Selesai & 14 orang \\
\hline tidak mengikuti & 2 orang \\
\hline mengikuti 1 x pertemuan & 4 orang \\
\hline mengikuti lebih 1 x pertemuan & 7 orang \\
\hline
\end{tabular}

Tabel 2: Jumlah guru mengikuti MGMP

Data tersebut dapat digambarkan dalam grafik sebagai berikut:

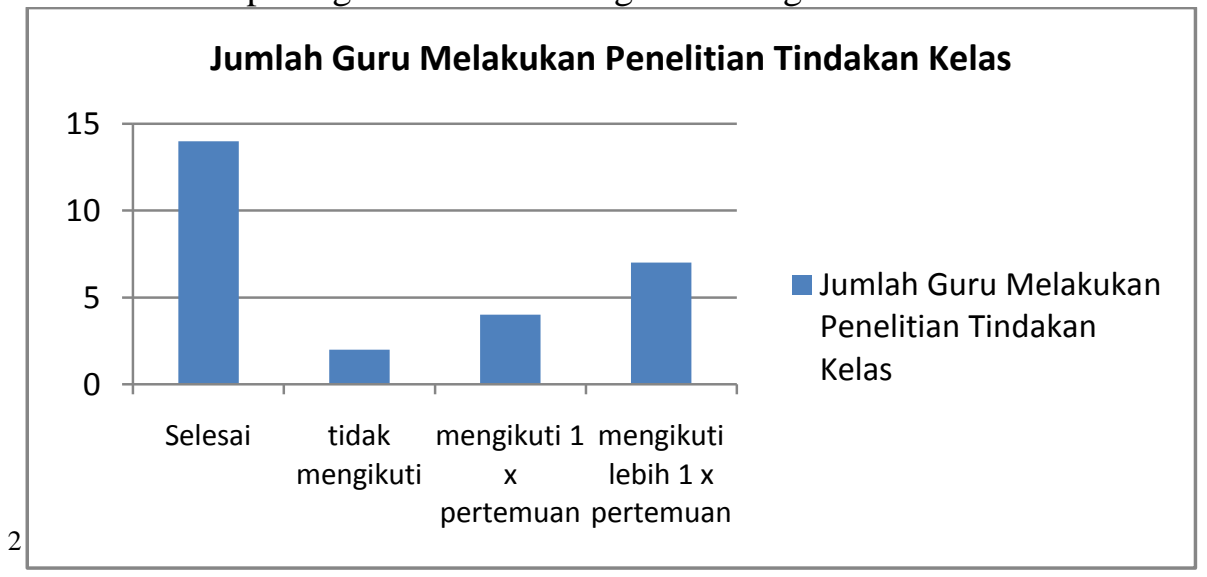

Grafik 2: Peserta MGMP di SMP N 23 Pontianak

Keadaan awal sebelum mengikuti MGMP di SMP Negeri 23 Pontianak sebanyak 2 orang guru pernah melakukan penelitian, dan setelah mengikuti MGMP ada sebanyak 14 orang yang selesai melakukan penelitian tindakan kelas. Ada peningkatan atau penambahan guru yang mempunyai kemampuan melakukan penelitian tindakan kelas sebanyak 12 orang. Sehingga masih ada 13 guru SMP Negeri 23 Pontianak yang belum dapat menyelesaikan penelitian tindakan kelas. Data tersebut dapat ditunjukkan dalam tabel berikut:

Kondisi Guru SMP N 23 Pontianak

Dapat Melakukan Penelitian Tindakan Kelas 


\begin{tabular}{|l|c|} 
Keadaan awal & 2 orang \\
\hline Keadaan akhir & 14 orang \\
\hline Peningkatan & 12 orang \\
\hline
\end{tabular}

Tabel 3: Jumlah guru dapat melakukan PTK

Data tersebut dapat digambarkan dalam grafik sebagai berikut:

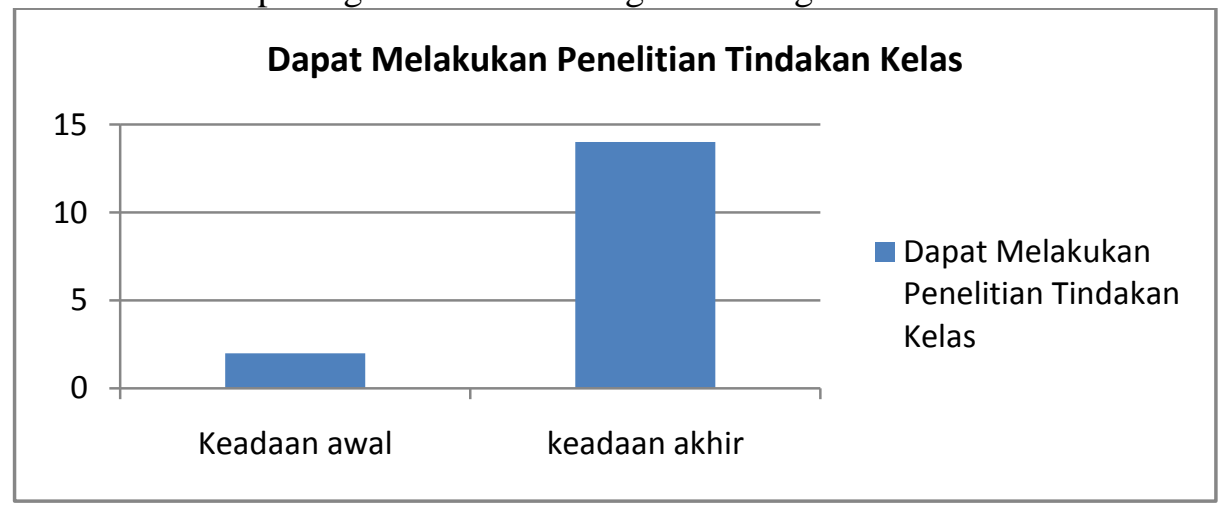

Grafik 3: Peningkatan Kompetensi Guru Melakukan PTK

Dari grafik diatas dapat disimpulkan bahwa setelah dilakukan MGMP di SMP Negeri 23 Pontianak ada peningkatan kompetensi guru dalam membuat penelitian tindakan kelas sebanyak 12 orang.

\section{Kesimpulan}

Dari pembahasan di atas dapat disimpulkan bahwa MGMP di SMP Negeri 23 Pontianak dapat meningkatkan kemampuan guru dalam membuat penelitian tindakan kelas. Dimana ketika kepala sekolah sebagai peneliti tindakan sekolah melakukan bimbingan pelaksanaan penelitian tindakan kelas, guru juga sebagai peneliti mempraktekan penelitian tindakan kelas Dari keseluruhan uraian termasuk pembahasan terhadap hasil yang diperoleh baik pada siklus I, siklus II, dan siklus III disimpulkan bahwa pelaksanaan MGMP di SMP Negeri 23 Pontianak yang diisi dengan bimbingan pelaksanaan penelitian tindakan kelas terbukti dapat meningkatkan kompetensi guru dalam membuat penelitian tindakan kelas.

Prosentase kompetensi guru dalam membuat penelitian tindakan kelas pada siklus I sebesar 38,82\% dan pada siklus II sebesar 78,33\%. Hal ini menunjukkan ada kenaikan kompetensi guru dalam membuat penelitian tindakan kelas sebesar 39,51\%. Ada kenaikan dari kategori berkemampuan rendah menjadi berkemampuan sangat tinggi. Pada akhir siklus III terjadi penambahan jumlah guru yang dapat melaksanakan penelitian tindakan kelas. 
Keadaan awal sebelum penelitian ada 2 guru yang pernah melakukan penelitian. Sedangkan keadaan akhir terdapat 14 guru yang dapat melakukan penelitian tindakan kelas.

\section{DAFTAR PUSTAKA}

Direktorat Tendik. 2010. Penelitian Tindakan Sekolah, Materi Pelatihan Penguatan Kemampuan Kepala Sekolah

Saryana. 2010. Peningkatan Motivasi Belajar Matematika Siswa Kelas IX A

SMP Negeri 1 Pontianak Melalui Pendekatan Kontekstual. Laporan Penelitian Tindakan Kelas, tidak diterbitkan.

Suhardjono, 2009. Tanya Jawab tentang PTK dan PTS, naskah buku .dan A. Aziz Hoesein, dkk (1995), Pedoman penyusunan

KTI di Bidang Pendidikan dan Angka Kredit Pengembangan Profesi Guru. Digutentis, Jakarta: Diknas

Malang

Suharsimi Arikunto, 2011. Penelitian Tindakan, Aditya Media, Yogyakarta .dkk, 2009. Penelitian Tindakan Kelas. PT. Bumi Aksara,

Jakarta

Offset

Suyanto, 1997, Pedoman Pelaksanaan Penelitian Tindakan Kelas, IKIP Yogyakarta.

Yogyakarta

2012, Calon Guru dan Guru Profesional, Multi Presindo,

Tutik R, dkk. 2012, Profesi Guru, Gava Media,Yogyakarta

U.Husna Asmara, 2007, Penulisan Karya Ilmiah, Fahruna Bahagia, Pontianak.

Undang-undang Republik Indonesia Nomor 14 Tahun 2005 tentang Guru dan Dosen. 2008. Jakarta: Visimedia. 